\title{
Hubungan Brand Equity (Brand Awarenees, Brand Associations, Perceived Quality) dengan Keputusan Pemanfaatan Klinik Laktasi di Rumah Sakit Muhammadiyah Lamongan
}

\author{
Fajar Ni'Syinta Armadani \\ Supriyadi \\ Nurnaningsih Herya Ulfah \\ Fakultas Ilmu Keolahragaan Univesitas Negeri Malang \\ email: syinta.armadani@gmail.com
}

\begin{abstract}
Abstrack: The visit number of patient at the lactation clinic of Muhammadiyah Lamongan Hospital tends to be small and decreases every year. A decrease in the visit number of patient may indicate that the utilization of health services is lacking. In utilizing health services, consumers are influenced by several considerations. One of affects consumer considerations is brand equity (brand awareness, brand associations, and perceived quality). This study aims to determine the relationship of brand equity (brand awareness, brand associations, and perceived quality) with the decision of lactation clinic utilization at Muhammadiyah Lamongan Hospital. This research used correlational quantitative design to know the relationship between brand awareness $\left(X_{1}\right)$, Brand Associations $\left(X_{2}\right)$, perceived quality $\left(X_{3}\right)$, with decision of utilization of lactation clinic at Muhammadiyah Lamongan Hospital $(Y)$. The population in this research was all patient who used lactation clinic at Muhammadiyah Lamongan Hospital and the sample were 32 patients, who visited the lactation clinic at Muhammadiyah Lamongan Hospital during April until May 2017. Technique of collecting data used questionnaire. Data analysis was correlation test, multiple linear regression test. Based on the results of the analysis, this study shows that there is a significant relationship simultaneously between brand awareness, brand associations, and perceived quality with the decision of utilization of lactation clinic at Muhammadiya Lamongan Hospital. Based on the result of coefficient of determination (R2) of 0.569 which means that Brand Awareness (X1), Brand Associations (X2), Perceived Quality (X3) have contribution equal to $56.9 \%$ to decision of utilization to laktasi clinic at Muhammadiyah Hospital Lamongan (Y).
\end{abstract}

Keywords: Brand Awareness, Brand Associations, Perceived Quality, Utilization of Health Care Service.

Abstrak: Jumlah kunjungan pasien di klinik laktasi Rumah Sakit Muhammadiyah Lamongan cenderung sedikit dan mengalami penurunan setiap tahun. Penurunan jumlah kunjungan pasien dapat menunjukkan bahwa pemanfaatan pelayanan kesehatan yang kurang.Dalam memanfaatkan pelayanan kesehatan,konsumen dipengaruhi oleh beberapa pertimbangan, salah satu yang mempengaruhi pertimbangan konsumen ialah Brand Equity.Penelitian ini dilaksanakan dengan tujuan untuk mencari hubungan antara Brand Awareness, Brand Associations, dan Perceived Quality dengan keputusan pemanfaatan klinik laktasi di Rumah Sakit Muhammadiyah Lamongan. Rancangan penelitian ini adalah kuantitatif korelasional dengan sampel sebanyak 32 orang. Teknik pengumpulan data menggunakan kuesioner. Analisis data menggunakan uji korelasi pearson dan uji regresi linier berganda. Hasil analisis penelitian didapatkan ada hubungan yang signifikan antara Brand awareness, Brand asssociations, Perceived quality secara bersama-sama dengan keputusan pemanfaatan klinik laktasi di Rumah Sakit Muhammadiyah. Berdasarkan hasil koefisien determinasi $\left(\mathrm{R}^{2}\right)$ sebesar 0,569 yang berarti bahwa Brand Awareness $\left(\mathrm{X}_{1}\right)$, Brand Associations $\left(\mathrm{X}_{2}\right)$, Perceived Quality $\left(\mathrm{X}_{3}\right)$ mempunyai kontribusi sebesar 56,9\% terhadap keputusan pemanfaatan terhadap klinik laktasi di Rumah Sakit Muhammadiyah Lamongan (Y).

Kata kunci: Brand Awareness, Brand Associations, Perceived Quality, Keputusan Pemanfaatan Pelayanan Kesehatan 
Berdasarkan Peraturan Pemerintah Republik Indonesia Nomor 33 Tahun 2012 tentang Pemberian Air Susu Ibu eksklusif (pasal 32), disebutkan bahwa penyelenggara fasilitas pelayanan kesehatan harus mendukung keberhasilan program pemberian Air Susu Ibu (ASI) eksklusif. Program pemberian ASI eksklusif di rumah sakit harus berpedoman pada sepuluh langkah menuju keberhasilan menyusui (Peraturan Pemerintah RI No. 33 Tahun 2012). Salah satu kegiatan dari sepuluh langkah menuju keberhasilan menyusui adalah dengan menjadi Rumah Sakit Sayang Bayi (Baby Friendly Hospital) dan didukung dengan adanya klinik laktasi. Klinik laktasi merupakan salah satu layanan kesehatan khusus menangani masalah menyusui dimana layanan ini merupakan wujud partisipasi rumah sakit dalam membantu upaya pemerintah dalam program menyukseskan program Rumah Sakit Sayang Bayi (Baby Friendly Hospital) (Kementerian Kesehatan RI, 2011).

Hasil Riset Fasilitas Kesehatan tahun 2011 menunjukkan bahwa Rumah Sakit Umum (RSU) Pemerintah di Indonesia yang mempunyai klinik laktasi hanya 34\%, persentase RSU Pemerintah di Jawa Timur yang memiliki klinik laktasi yaitu 36,0\% dan hanya $8 \%$ RSU Pemerintah yang memenuhi kriteria Rumah Sakit Sayang Bayi (Baby Friendly Hospital) (Kementerian Kesehatan RI, 2011). Berdasarkan penelitian oleh Kurniawan (2013:7) terdapat faktor pre/postnatal yang berpengaruh terhadap keberhasilan ibu memberikan ASI eksklusif yaitu kunjungan ke klinik laktasi.

Data Profil Kesehatan Kabupaten Lamongan tahun 2014 menunjukkan bahwa jumlah seluruh rumah sakit di Kabupaten Lamongan pada tahun 2014 adalah sebelas rumah sakit dengan rincian dua Rumah Sakit Umum Daerah (RSUD), kemudian enam rumah sakit milik swasta dan tiga rumah sakit khusus (Kementerian Kesehatan RI, 2014). Menurut Sistem Informasi Rumah Sakit Kementerian Kesehatan (SIRS KEMKES), rumah sakit di Kabupaten
Lamongan yang mempunyai layanan unggulan klinik laktasi adalah Rumah Sakit Muhammadiyah Lamongan (Kementerian Kesehatan RI, 2016). Rumah Sakit Muhammadiyah Lamongan mempunyai peran penting sebagai perintis Rumah Sakit Sayang Bayi (Baby Friendly Hospital) di Kabupaten Lamongan serta menjadi satu-satunya rumah sakit di Kabupaten Lamongan yang mempunyai klinik laktasi. Sehingga keberadaan klinik laktasi di rumah sakit ini penting dan harus dipertahankan agar rumah sakit lain dapat ikut mengembangkan klinik laktasi (Kementerian Kesehatan RI, 2014).

Rumah sakit yang ada di Kabupaten Lamongan mempunyai pelayanan yang mirip dengan klinik laktasi seperti poli Kesehatan Ibu dan Anak (KIA) dan layanan di klinik bidan. Banyaknya jumlah rumah sakit yang mempunyai pelayanan yang mirip tersebut menyebabkan pilihan konsumen semakin beragam. Selain itu, konsumen yang tidak mengetahui klinik laktasi cenderung lebih memanfaatkan layanan kesehatan bagi ibu dan anak yang lebih dulu populer dan banyak digunakan seperti poli KIA dan pelayanan klinik bidan. Rumah sakit yang memberikan pelayanan yang bermutu dan mempunyai citra yang baik yang akan menjadi pilihan konsumen dan dapat bertahan (Alamsyah, 2013).

Data rekam medik Rumah Sakit Muhammadiyah Lamongan menunjukkan bahwa jumlah kunjungan klinik laktasi pada pada tahun 2014 terdapat 76 orang, tahun 2015 ada 110 orang dan pada tahun 2016 ada 94 orang (Rumah Sakit Muhammadiyah Lamongan, 2016). Data tersebut menunjukkan bahwa jumlah kunjungan pada klinik laktasi sedikit, tidak menentu atau fluktuatif, dan cenderung mengalami penurunan. Hal ini menunjukkan tingkat pemanfaatan oleh masyarakat juga tidak menentu, sehingga dikhawatirkan masyarakat tidak menggunakan klinik laktasi di Rumah Sakit Muhammadiyah Lamongan di waktu yang akan datang.

Konsumen dalam memanfaatkan 
pelayanan kesehatan akan melakukan pertimbangan sebelum memutuskan untuk memilih pelayanan tersebut. Salah satu pertimbangannya adalah merek. Merek merupakan identitas sebuah produk, kuat tidaknya sebuah merek klinik laktasi dapat diukur dengan mengukur brand equity klinik laktasi tersebut. Keputusan pembelian konsumen dipengaruhi oleh perilaku konsumen, maka untuk mempermudah konsumen dalam memutuskan suatu pembelian, pemasar dapat mempengaruhi perilaku konsumen dengan kekuatan merek yaitu dengan cara menguatkan brand equity. Brand equity tersebut meliputi brand awareness, brand associations, dan perceived quality konsumen (Zen, 2012:11). Masalah dalam penelitian ini adalah jumlah kunjungan pasien klinik laktasi yang tidak menentu dan cenderung menurun. Hal tersebut menunjukkan bahwa pemanfaatan klinik laktasi menurun sehingga dikhawatirkan akan terus mengalami penurunan. Untuk mengetahui seberapa kuat brand equity dalam mempengaruhi konsumen dalam memanfaatkan klinik laktasi maka harus dilakukan sebuah penelitian mengenai brand equity berbasis pelanggan terhadap keputusan pembelian konsumen. Berdasarkan latar belakang tersebut, maka peneliti melakukan penelitian dengan judul "Hubungan Brand Equity (Brand Awareness, Brand Associations, Perceived Quality) dengan Keputusan Pemanfaatan Klinik Laktasi di Rumah Sakit Muhammadiyah Lamongan".

\section{METODE}

Metode penelitian yang digunakan adalah penelitian kuantitatif korelasional.Variabel bebas dalam penelitian ini adalah brand awareness, brand associations, dan perceived quality, sedangkan variabel terikat adalah keputusan pemanfaatan klinik laktasi di Rumah Sakit Muhammadiyah Lamongan. Sampel dalam penelitian ini adalah Ibu hamil dan ibu pasca melahirkan yang mengunjungi klinik laktasiyang memenuhi kriteria yang berjumlah 32 responden. Pengumpulan data dalam penelitian ini menggunakan kuesioner dengan teknik sampling yang digunakan adalah purposive sampling. Jadwal waktu pelaksanaan pengumpulan data dilaksanakan pada tanggal 1 April 2017 sampai dengan 31 Mei 2017. Analisis data yang digunakan adalah uji korelasi pearson dan analisis regresi linier berganda.

\section{HASIL PENELITIAN}

Statistik parametrik harus memenuhi asusmsi normalitas. Uji normalitas dilakukan untuk mengetahui apakah variabel penelitian berdistribusi normal atau tidak.Uji normalitas diujikan pada pada variabel penelitian Pengujian normalitas menggunakan teknik analisis Kolmogorov-Smirnov yang diolah dengan menggunakan software komputer, yang hasilnya dapat dilihat pada Tabel 1.Data dikatakan berdistribusi normal apabila nilai signifikansi lebih besar dari pada taraf signifikansi $\alpha=0,05$

Tabel 1 Hasil Uji Normalitas

\begin{tabular}{|l|l|l|l|c|}
\hline $\begin{array}{l}\text { Asymp. Sig. (2- } \\
\text { tailed) }\end{array}$ & $\begin{array}{l}\text { Brand } \\
\text { Awareness }\end{array}$ & $\begin{array}{l}\text { Brand } \\
\text { Associations }\end{array}$ & $\begin{array}{l}\text { Perceived } \\
\text { Quality }\end{array}$ & $\begin{array}{l}\text { Keputusan } \\
\text { Pemanfaatan }\end{array}$ \\
\cline { 2 - 5 } & 0,073 & 0,084 & 0,434 & 0,784 \\
\hline
\end{tabular}

Tabel 1 menunjukkan bahwa semua variabel memiliki nilai signifikansi lebih dari $\alpha=0,05$, maka semua variabel berdistribusi data normal. Oleh karena itu, penggunaan analisis satatistik parametrik dapat dilanjutkan.Pada analisis ini bertujuan untuk menguji hubungan antara variabel brand awareness $\left(\mathrm{X}_{1}\right)$ dengan keputusan pemanfaatan klinik laktasi di Rumah Sakit Muhammadiyah Lamongan (Y) dengan menggunakan uji regresi linier sederhana dan uji korelasi untuk mengetahui kekuatan hubungan antara kedua variabel tersebut. Hasil uji analisis 
regresi linier sederhana dapat dilihat pada

Tabel 2.

Tabel 2 Data Hasil Analisis Regresi Linier Sederhana

\begin{tabular}{lccc}
\hline \multirow{2}{*}{ Subvariabel } & Bnstandardized Coefficients & \multirow{2}{*}{ t-hitung } & \multirow{2}{*}{ Sig. } \\
\cline { 2 - 4 } & 29,189 & 6,137 & 0,000 \\
(Constant) & 3,315 & 2,525 & 0,017 \\
Brand Awareness & & B
\end{tabular}

Berdasarkan hasil analisis regresi linier sederhana pada Tabel 4.2 diperoleh persamaan regresi sebagai berikut: $\mathrm{Y}=29,189+3,315 \mathrm{X}_{1}$

Keterangan:

Y: Keputusan Pemanfaatan Klinik Laktasi di RSML

a: Konstanta

b: Koefisien Regresi

$\mathrm{X}_{1}$ : Brand Awareness

Berdasarkan persamaan tersebut maka dapat dijelaskan sebagai berikut.

1. Nilai konstanta (a) adalah 29,189, artinya jika Brand awareness nilainya adalah 0 maka tingkat keputusan pemanfaatan klinik laktasi di Rumah Sakit Muhammadiyah adalah sebesar 29,189.

2. Nilai koefisien regresi variabel Brand awareness (b) mempunyai nilai yang positif yaitu 3,315, maka Brand Awareness mempunyai hubungan yang positif terhadap keputusan pemanfaatan terhadap klinik laktasi RSML Artinya, bahwa setiap peningkatan Brand Awareness $\left(\mathrm{X}_{1}\right)$ satu kali maka keputusan pemanfaatan terhadap klinik laktasi RSML (Y) akan meningkat 3,315 kali.

Tabel 3 Hasil Korelasi Pearson

\begin{tabular}{cc}
\hline & Keputusan Pemanfaatan \\
\hline Brand Awareness Pearson Correlation & 0,419 \\
Sig. (2-tailed) & 0,017 \\
N & 32 \\
\hline
\end{tabular}

Tabel 3 menunjukkan nilai Pearson Correlation (r) diperoleh sebesar 0,419 artinya hubungan Brand awareness $\left(\mathrm{X}_{1}\right)$ dengan keputusan pemanfaatan klinik laktasi di Rumah Sakit Muhamamdiyah Lamongan (Y) adalah sebesar 0,419. Untuk mengetahui kekuatan hubungan dilakukan uji $t$ dengan ketentuan, jika $t_{\text {hitung }} \leq t_{\text {tabel }}$ maka hubungan antara Brand awareness dengan keputusan pemanfaatan klinik laktasi di Rumah Sakit Muhammadiyah adalah signifikan, tetapi sebaliknya jika $t_{\text {hitung }} \geq t_{\text {tabel }}$ maka hubungan antara Brand awareness dengan keputusan pemanfaatan klinik laktasi di Rumah Sakit Muhammadiyah tidak signifikan. Diperoleh bahwa $t_{\text {hitung }}(2,525)>t_{\text {tabel }}$ $(2,048)$ pada taraf signifikansi $(\alpha=0,05)$, artinya hubungan antara Brand awareness dengan keputusan pemanfaatan klinik laktasi di Rumah Sakit Muhammadiyah adalah signifikan. Analisis korelasi dapat dilanjutkan dengan menghitung koefisien determinasi dengan mengkuadratkan koefisien yang ditemukan. Jadi koefisien determinasi adalah $\mathrm{r}^{2}$ maka $0,419^{2}=0,1755$. Maka Brand Awareness $\left(\mathrm{X}_{1}\right)$ mempunyai kontribusi sebesar $17,55 \%$ terhadap keputusan pemanfaatan terhadap klinik laktasi di Rumah Sakit Muhammadiyah Lamongan (Y). Kemudian menguji hubungan antara variabel brand associations $\left(\mathrm{X}_{2}\right)$ dengan keputusan pemanfaatan klinik laktasi di Rumah Sakit Muhammadiyah Lamongan (Y), dapat dilihat pada Tabel 4 berikut ini. 
Tabel 4 Hasil Analisis Regresi Linier Sederhana

\begin{tabular}{lccc}
\hline \multirow{2}{*}{ Subvariabel } & $\begin{array}{c}\text { Unstandardized } \\
\text { Coefficients }\end{array}$ & t-hitung & Sig. \\
\cline { 2 - 3 } & $\mathbf{B}$ & 3,592 & 0,001 \\
(Constant) & 25,914 & 2,108 & 0,044 \\
\hline
\end{tabular}

Berdasarkan hasil analisis regresi linier pada Tabel 4 diperoleh persamaan regresi sebagai berikutY $=25,914+$ $0,395 \mathrm{X}_{2}$

Keterangan:

Y: Keputusan Pemanfaatan Klinik

Laktasi di RSML

a : Konstanta

b: Koefisien Regresi

$\mathrm{X}_{2}$ :Brand Associations

Berdasarkan persamaan tersebut maka dapat dijelaskan sebagai berikut.

1. Nilai konstanta (a) adalah 25,914, artinya jika Brand associations nilainya adalah 0 maka tingkat keputusan pemanfaatan klinik laktasi di Rumah Sakit Muhammadiyah adalah sebesar 25,914.

2. Nilai koefisien regresi variabel Brand associations (b) mempunyai nilai yang positif yaitu 0,395 , maka Brand associationsmempunyai hubungan yang positif terhadap keputusan pemanfaatan terhadap klinik laktasi RSML Artinya, bahwa setiap peningkatan Brand associations $\left(\mathrm{X}_{2}\right)$ satu kali maka keputusan pemanfaatan terhadap klinik laktasi RSML (Y) akan meningkat 0,395 kali.

Tabel 5 Hasil Uji Korelasi Pearson

\begin{tabular}{llc}
\hline & & Keputusan Pemanfaatan \\
\hline Brand Association & Pearson Correlation & 0,359 \\
& Sig. (2-tailed) & 0,044 \\
& N & 32 \\
\hline
\end{tabular}

Tabel 5 menunjukkan bahwa

nilai Pearson Correlation (r) diperoleh sebesar 0,359 artinya hubungan Brand associations $\left(\mathrm{X}_{2}\right)$ dengan keputusan pemanfaatan klinik laktasi di Rumah Sakit Muhamamdiyah Lamongan (Y) adalah sebesar 0,359. Untuk mengetahui kekuatan hubungan dilakukan uji $t$ dengan ketentuan, jika $t_{\text {hitung }} \leq t_{\text {tabel }}$ maka hubungan antara Brand associations dengan keputusan pemanfaatan klinik laktasi di Rumah Sakit Muhammadiyah adalah signifikan, tetapi sebaliknya jika $t_{\text {hitung }} \geq t_{\text {tabel }}$ maka hubungan antara Brand associations dengan keputusan pemanfaatan klinik laktasi di Rumah Sakit Muhammadiyah tidak signifikan. Diperoleh bahwa $t_{\text {hitung }}(2,108)>t_{\text {tabel }}$ $(2,048)$ pada taraf signifikansi $(\alpha=0,05)$, artinya hubungan antara Brand awareness dengan keputusan pemanfaatan klinik laktasi di Rumah Sakit Muhammadiyah adalah signifikan. Analisis korelasi dapat dilanjutkan dengan menghitung koefisien determinasi dengan mengkuadratkan koefisien yang ditemukan. Jadi koefisien determinasi adalah $\mathrm{r}^{2}$ maka $0,359^{2}=0,1288$. Maka Brand Associations $\left(\mathrm{X}_{2}\right)$ mempunyai kontribusi sebesar $12,88 \%$ terhadap keputusan pemanfaatan terhadap klinik laktasi di Rumah Sakit Muhammadiyah Lamongan (Y). Kemudian menguji hubungan antara variabel Perceived quality $\left(\mathrm{X}_{3}\right)$ dengan keputusan pemanfaatan klinik laktasi di Rumah Sakit Muhammadiyah Lamongan (Y), dapat dilihat pada Tabel 6 berikut ini. 
Tabel 6 Hasil Analisis Regresi Linier Sederhana

\begin{tabular}{lcccc}
\hline \multirow{2}{*}{ Subvariabel } & \multicolumn{2}{c}{ Unstandardized Coefficients } & \multirow{2}{*}{ t-hitung } & \multirow{2}{*}{ Sig. } \\
\cline { 2 - 3 } & $\mathbf{B}$ & Std. Error & & \\
\hline (Constant) & 70,532 & 7,785 & 9,060 & 0,000 \\
Perceived quality & $-0,770$ & 0,202 & $-3,813$ & 0,001 \\
\hline
\end{tabular}

Berdasarkan hasil analisis regresi linier pada Tabel 6 diperoleh persamaan regresi sebagai berikut: $\mathrm{Y}=70,532$ $0,770 X_{3}$

Keterangan:

Y: Keputusan Pemanfaatan Klinik

Laktasi di RSML

a : Konstanta

b: Koefisien Regresi

$\mathrm{X}_{3}$ : Perceived Quality

Berdasarkan persamaan tersebut maka dapat dijelaskan sebagai berikut.

1. Nilai konstanta (a) adalah 70,532, artinya jika Perceived quality nilainya adalah 0 maka tingkat keputusan pemanfaatan klinik laktasi di Rumah Sakit Muhammadiyah adalah sebesar 70,532 .

2. Nilai koefisien regresi variabel Perceived quality (b) mempunyai nilai yang negatif adalah $-0,770$ maka Perceived quality mempunyai hubungan yang negatif/berlawanan terhadap keputusan pemanfaatan terhadap klinik laktasi RSML. Artinya, bahwa setiap peningkatan Perceived quality $\left(\mathrm{X}_{3}\right)$ satu kali maka keputusan pemanfaatan terhadap klinik laktasi RSML (Y) akanmengalami penurunan 0,770 kali.

Tabel 7 Hasil UjiKorelasi Pearson

\begin{tabular}{llc}
\hline & & Keputusan Pemanfaatan \\
\hline Perceived Quality & Pearson Correlation & 0,517 \\
& Sig. (2-tailed) & 0,001 \\
& N & 32 \\
\hline
\end{tabular}

Tabel 7 menunjukkan nilai Pearson Correlation (r) adalah sebesar 0,517 artinya hubungan Perceived quality $\left(\mathrm{X}_{3}\right)$ dengan keputusan pemanfaatan klinik laktasi di Rumah Sakit Muhamamdiyah Lamongan (Y) adalah sebesar 0,517. Untuk mengetahui kekuatan hubungan dilakukan uji $t$ dengan ketentuan, jika $t_{\text {hitung }} \leq t_{\text {tabel }}$ maka hubungan antara Perceived quality dengan keputusan pemanfaatan klinik laktasi di Rumah Sakit Muhammadiyah adalah signifikan, tetapi sebaliknya jika $t_{\text {hitung }} \geq t_{\text {tabel }}$ maka hubungan antara Perceived quality dengan keputusan pemanfaatan klinik laktasi di Rumah Sakit Muhammadiyah tidak signifikan. Diperoleh bahwa $t_{\text {hitung }}(2,108)>t_{\text {tabel }}$ $(2,048)$ pada taraf signifikansi $(\alpha=0,05)$, artinya hubungan antara Brand awareness dengan keputusan pemanfaatan klinik laktasi di Rumah
Sakit Muhammadiyah adalah signifikan. Analisis korelasi dapat dilanjutkan dengan menghitung koefisien determinasi dengan mengkuadratkan koefisien yang ditemukan. Jadi koefisien determinasi adalah $\mathrm{r}^{2}$ maka $0,517^{2}=$ 0,2672. Maka Perceived quality $\left(\mathrm{X}_{3}\right)$ mempunyai kontribusi sebesar $26,72 \%$ terhadap keputusan pemanfaatan terhadap klinik laktasi di Rumah Sakit Muhammadiyah Lamongan (Y). Setelah dilakukan uji korelasi setiap variabel independen secara sendiri-sendiri dengan variabel dependen, selanjutnya dilakukan uji secara bersama-sama variabel Brand awareness $\left(\mathrm{X}_{1}\right)$, Brand associations $\left(\mathrm{X}_{2}\right)$, dan Perceived quality $\left(\mathrm{X}_{3}\right)$ dengan keputusan pemanfaatan klinik laktasi di Rumah Sakit Muhammadiyah Lamongan (Y), dapat dilihat pada Tabel 8. 
Tabel 8 Rangkuman Hasil Analisis Regresi Linier Berganda

\begin{tabular}{lccc}
\hline \multirow{2}{*}{ Subvariabel } & Unstandardized Coefficients & \multirow{2}{*}{ t-hitung } & \multirow{2}{*}{ Sig. } \\
\cline { 2 - 3 } & B & 3,596 & 0,001 \\
(Constant) & 40,339 & 1,815 & 0,080 \\
Brand Awareness & 2,042 & 3.740 & 0,001 \\
Brand Associations & 0,519 & -3.622 & 0,001 \\
Perceived Quality & $-0,689$ & & \\
\hline $\mathrm{R}$ & 0,755 & & \\
$\mathrm{R}$ Square $\left(\mathrm{R}^{2}\right)$ & 0,569 & & \\
F Hitung & 12,344 & & \\
F Sig. & 0,000 & & \\
\hline
\end{tabular}

Berdasarkan hasil analisis linier regresi maka diperoleh persamaan regresi sebagai berikut: $\mathrm{Y}=40,339+2,042 \mathrm{X}_{1}+$ $0,519 \mathrm{X}_{2}-0,689 \mathrm{X}_{3}+\mathrm{e}$

Keterangan :

Y: Keputusan Pemanfaatan Klinik Laktasi di RSML

a: Konstanta

$\mathrm{b}_{1}-\mathrm{b}_{3}$ : Koefisien Regresi

$\mathrm{X}_{1}$ : Brand Awareness

$\mathrm{X}_{2}$ : Brand Associations

$\mathrm{X}_{3}$ : Perceived Quality

e : Standar Error

Berdasarkan persamaan tersebut, maka dapat dijelaskan sebagai berikut.

1. Nilai konstanta (a) adalah 40,339. Artinya, jika Brand Awareness $\left(\mathrm{X}_{1}\right)$, Brand Associations $\left(\mathrm{X}_{2}\right)$, Perceived Quality $\left(\mathrm{X}_{3}\right)$ nilainya 0 maka tingkat keputusan pemanfaatan terhadap klinik laktasi di RSML nilainya sebesar 40,339 atau dengan kata lain variabel keputusan pemanfaatan terhadap klinik laktasi di RSML akan konstan sebesar 40,339 jika tidak dipengaruhi brand awareness $\left(\mathrm{X}_{1}\right)$, brand associations $\left(\mathrm{X}_{2}\right)$, perceived quality $\left(\mathrm{X}_{3}\right)$.

2. Nilai koefisien regresi variabel Brand Awareness (b1) mempunyai nilai yang positif, yaitu 2,042. Artinya bahwa setiap peningkatan Brand Awareness $\left(\mathrm{X}_{1}\right)$ satu kali maka keputusan pemanfaatan terhadap klinik laktasi RSML (Y) akan meningkat 2,042 kali.

3. Nilai koefisien regresi variabel Brand Associations (b2) mempunyai nilai yang positif, yaitu 0,519. Artinya bahwa setiap peningkatan Brand Associations $\left(\mathrm{X}_{2}\right)$ satu kali maka keputusan pemanfaatan terhadap klinik laktasi RSML (Y) akan meningkat0,519 kali.

4. Nilai koefisien regresi variabel Perceived Quality (b3) mempunyai nilai yang negatif $-0,689$, maka mempunyai hubungan yang berlawanan. Artinya bahwa setiap peningkatan Perceived Quality $\left(\mathrm{X}_{3}\right)$ satu kali maka akan diikuti oleh penurunan keputusan pemanfaatan terhadap klinik laktasi RSML (Y) sebesar 0,689 kali.

Kesimpulan dari persamaan regresi tersebut adalah jika variabel Brand Awareness $\left(\mathrm{X}_{1}\right)$ sebesar 2,042, variabel Brand Associations $\left(\mathrm{X}_{2}\right)$ sebesar 0,519 dan variabel Perceived Quality $\left(\mathrm{X}_{3}\right)$ sebesar $-0,689$ maka variabel keputusan pemanfaatan terhadap klinik laktasi di RSML adalah sebesar 40,339.

Berdasarkan hasil analisis pada Tabel 8 diperoleh nilai koefisien korelasi secara bersama-sama ( $\mathrm{R}$ ) adalah sebesar 0,755 , artinya hubungan antara variabel Brand awareness $\left(\mathrm{X}_{1}\right), \quad$ Brand associations $\left(\mathrm{X}_{2}\right)$,Perceived quality $\left(\mathrm{X}_{3}\right)$ dengan keputusan pemanfaatan klinik laktasi di Rumah Sakit Muhammadiyah Lamongan (Y) adalah kuat karena nilai mendekati satu. Kemudian nilai koefisien determinasi $\left(\mathrm{R}^{2}\right)$ pada Tabel 8 adalah sebesar 0,569 yang berarti bahwa Brand Awareness $\left(\mathrm{X}_{1}\right)$, Brand Associations $\left(\mathrm{X}_{2}\right)$, Perceived Quality $\left(\mathrm{X}_{3}\right)$ mempunyai kontribusi sebesar $56,9 \%$ terhadap keputusan pemanfaatan terhadap klinik laktasi di Rumah Sakit Muhammadiyah Lamongan (Y). Sedangkan sisanya $43,2 \%$ dijelaskan oleh variabel-variabel lain yang tidak digunakan dalam penelitian ini. Setelah diketahui nilai koefisien korelasinya (r) kemudian dicari 
kekuatan hubungannya menggunakan uji F (uji simultan) dengan ketentuan jika $\mathrm{F}_{\text {hitung }} \leq \mathrm{F}_{\text {tabel }}$ maka terdapat hubungan antara Brand awareness, Brand asssociations, Perceived quality secara bersama-sama terhadap keputusan pemanfaatan klinik laktasi di Rumah Sakit Muhammadiyah, tetapi sebaliknya jika $F_{\text {hitung }} \geq F_{\text {tabel }}$ maka tidak terdapat hubungan antara Brand awareness, Brand asssociations, Perceived quality secara bersama-sama dengan keputusan pemanfaatan klinik laktasi di Rumah Sakit Muhammadiyah. Diperoleh bahwa $F_{\text {hitung }}(12,344)>F_{\text {tabel }}(3,32)$ pada taraf signifikansi $(\alpha=0,05)$, artinya terdapat hubungan antara Brand awareness, Brand asssociations, Perceived quality secara bersama-sama dengan keputusan pemanfaatan klinik laktasi di Rumah Sakit Muhammadiyah secara signifikan.

\section{PEMBAHASAN}

\section{Hubungan Brand Awareness dengan Keputusan Pemanfaatan Klinik Laktasi di Rumah Sakit Muhammadiyah Lamongan}

Hasil penelitian menunjukkan bahwa terdapat hubungan antara brand awareness dengan keputusan pemanfaatan klinik laktasi di Rumah Sakit Muhammadiyah Lamongan (RSML). Hal ini dapat dikarenakan brand awareness mempengaruhi rasa percaya diri pelanggan atas keputusan pembelian yang dilakukan. Menurut Fatimah (2014) jika perusahaan dapat membangun merek yang kuat di pikaran pelanggan dengan strategi yang kuat maka merek tersebut akan memiliki nilai tambah bagi pelanggan yaitu memiliki brand awareness, oleh karena itu pengingatan kembali sangat penting terhadap keputusan pembelian pada konsumen karena konsumen akan cenderung memilih yang biasa mereka pakai dalam kehidupan sehari hari. Selain itu, menurut penelitian yang dilakukan oleh Ahmad, dkk. (2016) menyebutkan bahwa brand awareness merupakan proses mulai terjadinya komunikasi antara konsumen dan perusahaan/instansi, yang artinya bahwa konsumen butuh mengenal sebuah merek terlebih dahulu sebelum memutuskan melakukan pembelian.

Hal ini juga dapat terjadi karena menurut hasil penelitian menunjukkan bahwa responden memiliki brand awareness dalam kategori paling tinggi yaitu top of mind $(65,6 \%)$, yang artinya responden memiliki kemampuan untuk mengenali dan memiliki kemampuan mengingat klinik laktasi yang ada di Rumah Sakit Muhammadiyah Lamongan pada level top of mind secara detail. Para responden yang masuk dalam kategori top of mind merupakan responden yang sudah pernah menggunakan layanan kesehatan tersebut (Nugroho, 2013) dan kemungkinan karena mereka memang belum pernah berkunjung ke rumah sakit lain selain klinik laktasi di RSML (Rimiyati \& Astutu, 2012). Menurut penelitan yang dilakukan oleh Shahid et al. (2017) bahwa konsumen akan membeli sebuah produk yangsudah mereka ketahui dan kenali dengan baik.

Responden menyebutkan beberapa rumah sakit di Kabupaten Lamongan yang menjadi pilihan rumah sakit lain. Dari semua rumah sakit tersebut, yang harus menjadi perhatian adalah RSIA X dan RSUD Y, karena menjadi pilihan lain responden dalam nomor satu. RSIA $X$ merupakan rumah sakit khusus ibu dan anak yang sudah mempunyai dokterdokter yang sudah dikenal terbaik oleh masyarakat. Tidak adanya pelanggan masuk dalam kategori unaware of brand atau tidak menyadari adanya klinik laktasi di RSML dapat disebabkan oleh karena penelitian dilakukan di dalam lingkungan RSML yang mengakibatkan seluruh responden menyadari adanya klinik laktasi di RSML.

Sumber informasi utama yang menjadi alasan konsumen menggunakan klinik laktasi adalah responden menggunakan klinik laktasi karena atas rekomendasi petugas kesehatan RSML (dokter, perawat, dan lain-lain) sebanyak $61,5 \%$. Responden menggunakan klinik laktasi karena sebelumnya menggunakan klinik anak di RSML, ketika terdapat masalah dengan ASI dan menyusui maka 
dokter klinik anak merekomendasikan pasien ke klinik laktasi RSML. Selain itu, rekomendasi dokter juga didapatkan ketika responden melakukan persalinan di RSML dan apabila terdapat masalah mengenai ASI dan menyusui, maka pasien diharuskan mendapatkan layanan klinik laktasi. Artinya, responden menggunakan klinik laktasi tidak karena keinginan sendiri melainkan rekomendasi dari dokter untuk menggunakan klinik laktasi. Hal ini dapat terjadi karena dari awal responden memanfaatkan klinik laktasi dipengaruhi oleh orang lain maka menyebabkan keputusan awal untuk memanfaatkan klinik laktasi bukan berasal dari diri responden. Sehingga dapat mempengaruhi future use jika responden menggunakan klinik laktasi karena tidak menyadari bahwa klinik laktasi sesuai dengan kebutuhan mereka.

Tidak terdapat responden yang mendapatkan informasi pertama kali dari brosur/leaflet. Hal ini dapat disebabkan karena semua brosur mengenai layanan kesehatan di RSML hanya diletakkan di pintu masuk utama rumah sakit, tidak di setiap ruang tunggu poli sehingga kemungkinan responden tidak mengetahui dan tidak tertarik untuk mengambilnya.

Konsumen dapat mengenal klinik laktasi RSML dengan memperbanyak sumber informasi klinik laktasi RSML yaitu melalui bauran promosi seperti iklan. Iklan dapat digunakan untuk tujuan membentuk kesadaran terhadap sebuah merek (Vinodhini \& Kumar, 2010), dengan cara menyampaikan pesan dari merek tersebut. Seperti iklan komersial di radio, surat kabar, promosi penjualan, publisitas/temu pelanggan, getok tular (word of mouth), dan menciptakan sebuah slogan dan tag line. Pesan dari klinik laktasi yang ingin dikomunikasikan juga harus konsisten dilihat oleh orang banyak sepanjang hari, berasa dipusat keramaian. Jika pesan atau slogan yang disampaikan cukup menarik, maka lambat laun orang akan menyimpan informasi tersebut. Menurut Alhaddad (2015) kesadaran terhadap merek dapat dibangun dengan membuat advertising awareness melalui sosial media dengan menggunakan foto atau info grafis sehingga dapat menciptakan memorable advertising terhadap sebuah merek dan dapat dibagikan terhadap sesama teman di sosial media.

\section{Hubungan Brand Associations dengan Keputusan Pemanfaatan Klinik Laktasi di Rumah Sakit Muhammadiyah Lamongan}

Hasil penelitian menunjukkan terdapat hubungan antara brand associations dengan keputusan pemanfaatan klinik laktasi di Rumah Sakit Muhammadiyah Lamongan (RSML). Hal ini dapat terjadi karena brand associations mampu mempengaruhi konsumen dalam melakukan keputusan pembelian dengan membangkitkan alasan untuk membeli merek tersebut. Asosiasi juga bisa menciptakan informasi bagi pelanggan dan bisa mempengaruhi pengingatan kembali atas informasi tersebut, terutama pada saat membuat keputusan. Hasil analisis menunjukkan bahwa sebesar $100 \%$ responden menyatakan mendapatkan informasi mengenai cara perawatan payudara bagi ibu hamil/ibu menyusui dari klinik laktasi RSML dan sebesar $100 \%$ responden meyatakan klinik laktasi RSML sangat bermanfaat untuk mendapatkan solusi dari masalah Air Susu Ibu (ASI)/menyusu. Dari data tersebut dapat diketahui bahwa responden menggunakan klinik laktasi di RSML karena alasan manfaat yang diperoleh sehingga responden mengasosiasikan klinik laktasi di RSML dengan manfaat yang dapat diperoleh dari klinik laktasi. Sesuai dengan teori Tuominen P. (1999) yang menyebutkan bahwa brand associations dapat membangkitkan berbagai atribut produk atau manfaat bagi konsumen (costumer benefits) yang dapat memberikan alasan spesifik bagi konsumen untuk membeli dan menggunakan merek tersebut. Konsumen percaya bahwa klinik laktasi memiliki atribut atau manfaat yang memenuhi kebutuhan dan keinginan mereka. Didukung oleh penelitian dari Setyawati \& Rochmah (2015) bahwa keberhasilan 
program pemasaran direfleksikan melalui penciptaan asosiasi merek yang disukai, yakni ketika konsumen percaya bahwa suatu merek memiliki atribut dan manfaat yang dapat memenuhi kebutuhan dan keinginan konsumen sehingga secara keseluruhan membentuk sikap yang positif terhadap merek tersebut. Jika asosiasi yang positif terhadap suatu merek maka akan mendorong konsumen untuk memakai merek. Konsumen akan cenderung memakai merek yang dianggap oleh masyarakat sebagai merek baik, berkualitas, handal, dan lain sebagainya. Merek yang mempunyai asosiasi yang baik di mata masyarakat biasanya akan mudah diterima.

Hasil penelitian juga menunjukan bahwa sebesar 56,3\% responden menyatakan pelayanan yang diperoleh di klinik laktasi di RSML, poli Kesehatan Ibu dan Ana (KIA) dan klinik bidan adalah sama. Artinya, responden menganggap pelayanan yang ada di klinik laktasi RSML bisa di dapatkan di poli KIA rumah sakit lain dan klinik bidan. Hal ini dapat disebabkan karena di poli KIA rumah sakit lain dan klinik bidan juga memberikan layanan konsultasi laktasi.

Hasil penelitian terhadap brand associations juga menunjukkan sebesar $59,4 \%$ responden menyatakan brand associations klinik laktasi RSML masuk dalam kategori sedang, hal ini dikarenakan responden dapat mengetahui dan merasakan manfaat dari klinik laktasi RSML tetapi masih merasa bahwa manfaat tersebut juga bisa didapatkan di pelayanan lain yang sama diperuntukkan bagi ibu dan anak yaitu, klinik ibu dan anak dan klinik praktek bidan. RSML harus melakukan kegiatan-kegiatan yang ditujukan untuk meningkatkan brand associations bagi pelanggan serta masyarakat yang belum mengetahui klinik laktasi di RSML. Sangat penting meningkatkan asosiasi pelanggan terhadap klinik laktasi RSML yaitu dengan memberikan suatu pembeda dengan klinik pesaingnya. Salah satunya adalah dengan mengasosiasikan klinik laktasi dengan suatu faktor yang memiliki keunikan dalam hal competitive advantage (keunggulan kompetitif) yang mampu memberikan suatu alasan bagi pelanggan mengapa mereka harus menggunakan klinik laktasi di RSML baik dari aspek price, product, personnel, dan service. Competitive advantage (keunggulan bersaing) adalah kumpulan keunikan bentuk suatu organisasi dan produk atau jasa yang dirasakan oleh konsumen sebagai hal superior dan berarti dibandingkan pesaingnya (Supriyanto \& Ernawaty, 2010). Hasil penelitian menemukan bahwa pelanggan mengasosiasikan klinik laktasi dengan manfaat bagi pelanggan, sehingga manfaat bagi pelanggan tersebut menjadi asosiasi yang paling menonjol bagi klinik laktasi. Oleh karena itu, asosiasi terhadap manfaat produk layanan dari klinik laktasi harus dikembangkan menjadi produk yang lebih inovatif, bervariasi, dan menciptakan keunikan-keunikan baru guna mencegah peniruan oleh pesaing dan selalu menjadi pilihan pertama konsumen. Cara lain dapat dilakukan dengan menggunakan atribut tak berwujud yaitu seperti mengasosiasikan klinik laktasi dengan dokter yang professional. Seperti yang telah dilakukan oleh poli anak di RSML yang telah berhasil mengasosiasikan poli tersebut dengan nama seorang dokter, sehingga alasan konsumen menggunakan poli tersebut adalah karena dokter tersebut. Akan tetapi, rumah sakit tidak boleh bergantung pada nama seorang dokter, karena jika dokter tersebut tidak ada lagi maka akan berdampak besar bagi angka kunjungan. Oleh karena itu, RSML harus berupaya memiliki banyak dokter yang berkualitas dalam semua bidang agar asosiasi pelanggan tidak pada nama dokternya tetapi berubah menjadi setiap berobat ke RSML pasti dilayani oleh dokter yang professional, siapapun dokternya. Seperti penelitian yang dilakukan oleh Nurulaini (2010) bahwa pengembangan asosiasi ini bisa berbahaya dan memungkinkan mendapatkan suatu tingkat asosiasi produk yang berada diluar kontrol perusahaan misalnya dalam mengandalkan nama seorang dokter. Jika rumah sakit 
bergantung pada nama seorang dokter, dan dokter tersebut tidak bertugas lagi maka akan berdampak besar bagi angka kunjungan.

\section{Hubungan Perceived Quality dengan Keputusan Pemanfaatan Klinik Laktasi di Rumah Sakit Muhammadiyah Lamongan}

Hasil penelitian menunjukkan bahwa terdapat hubungan antara perceived quality dengan keputusan pemanfaatan klinik laktasi di Rumah Sakit Muhammadiyah Lamongan (RSML). Menurut Hussein (2012), perceived quality merupakan alasan kenapa sebuah merek dipertimbangkan dan dibeli. Persepsi konsumen terhadap kualitas sebuah pelayanan akan mempengaruhi persepsi keseluruhan nilai dan akhirnya akan mempengaruhi keputusan pembelian dalam layanan kesehatan. Hal ini dapat dilihat pada hasil penelitian yang menunjukkan bahwa sebesar $100 \%$ responden menyatakan bahwa petugas kesehatan di klinik laktasi RSML tidak ragu menetapkan diagnosa, hal ini berarti bahwa responden merasakan jaminan kualitas dari klinik laktasi RSML. Hal ini menunjukkan bahwa klinik laktasi RSML memiliki perceived quality yang baik karena rumah sakit sudah melakukan komitmen pada kualitas dengan selalu melayani pasien dengan baik. Melalui perceived quality konsumen akan mulai yakin terhadap merek yang telah dikenal dan telah dipilih sesuai dengan kebutuhannya (Nugraha, 2104), sehingga konsumen akan menjadi loyal terhadap klinik laktasi RSML.

Hasil penelitian menunjukkan bahwa sebesar $68,8 \%$ responden menyatakan perceived quality terhadap klinik laktasi RSML masuk dalam kategori sedang, hal ini dapat terjadi karena sebesar $84,4 \%$ responden menyatakan tidak ada dokter yang berjaga di klinik laktasi RSML. Dengan tidak adanya dokter di klinik laktasi RSML dapat mengurangi keterandalan klinik laktasi RSML dalam memberikan pelayanan di mata pelanggan.
Klinik laktasi di RSML dijalankan oleh tim klinik laktasi yang terdiri dari berbagai macam praktisi karena pelayanan yang didapatkan oleh pasien di klinik laktasi disesuaikan dengan keluhan pasien, tim melaksanakan pelayanan secara kondisional, yang artinya ketika ada pasien yang berkunjung ke klinik laktasi baru akan menuju ke ruang klinik laktasi, sehingga tidak ada yang berjaga di ruangan. Petugas kesehatan yang melakukan konseling di klinik laktasi adalah perawat dan bidan bukan dokter, hal ini dapat mengurangi harapan pasien untuk segera ditangani oleh dokter. Rumah sakit dapat menambahkan dokter khusus di klinik laktasi yang memiliki sertifikat International Board Certified Lactation Consultant (IBCLC). IBCLC merupakan sertifikat standar internasional bagi konsultan laktasi di rumah sakit atu klinik (Brooks et al., 2015). Jika RSML memiliki dokter dengan IBCLC maka akan menjadi satu-satunya di Kabupaten Lamongan, dokter dengan IBCLC dapat dijadikan sebagai faktor pembeda dengan dokter-dokter di klinik lain dan RSML dikenal sebagai Rumah Sakit yang mempunyai klinik laktasi yang terbaik kualitasnya. Selain itu dokter IBCLC dapat menjadi daya tarik pasien datang untuk menggunakan klinik laktasi RSML.

Hasil penelitian juga menyebutkan bahwa sebesar $65,7 \%$ responden menyatakan peralatan penunjang medis di klinik laktasi kurang memadai. Hal ini dapat terjadi karena ruangan operasional klinik laktasi RSML berada di ruangan poli anak, sehingga pelayanannya terkadang terganggu dengan pasien lain yang sedang berobat di poli anak. Klinik laktasi RSML merupakan pelayanan kesehatan yang terintegrasi dengan poli anak, dan yang memiliki peran penting adalah perawat poli anak karena bertugas memanggil petugas kesehatan dari petugas klinik laktasi. Oleh karena itu, agar lebih efisien ruangan poli anak digunakan sekaligus sebagai ruangan klinik laktasi. Klinik laktasi RSML memiliki ruangan untuk 
pelayanan sendiri, tepat bersebelahan dengan ruangan poli anak, tetapi ruangan tersebut tidak digunakan karena pasien yang datang ke klinik laktasi hanya sedikit sehingga tidak ada dokter dan perawat yang berjaga di ruangan.

RSML harus meningkatkan kualitas pelayanan yang tidak sesuai dengan harapan pelanggannya. Menurut Poernomo, dkk. (2011), klinik laktasi harus didukung oleh fasilitas yang cukup yaitu meliputi:

1. Ruang dan peralatan untuk pemeriksaan payudara dan perawatan payudara serta pemeriksaan bayi

2. Ruang penyuluhan dan alat yang diperlukan seperti, boneka, leaflet, Over Head Projektor (OHP), video, poster, food model, Kartu Menuju Sehat (KMS) ibu hamil dan KMS balita, serta catatan medik klinik laktasi. Sarana dapat disesuaikan dengan kondisi masing-masing.

Rumah sakit harus berusaha untuk memenuhi kualitas berdasarkan persepsi pelanggan. Kualitas berdasarkan persepsi pelanggan dapat diperoleh dengan memperhatikan semua pelanggannya, sehingga dapat mengetahui apa yang disukai maupun yang tidak disukai serta apa yang diharapkan pelanggan (Nurulaini, 2010). Menurut hasil penelitian pada variabel keputusan pembelian menunjukkan bahwa dalam proses keputusan pemanfaatan klinik laktasi di RSML, responden melakukan identifikasi kebutuhan yaitu menurut hasil penelitian sebesar 100\% responden menggunakan klinik laktasi di RSML karena untuk berkonsultasi dengan dokter, artinya adalah klinik laktasi menjadi salah satu pilihan konsumen ketika mempunyai masalah. Kemudian, proses selanjutnya adalah mencari informasi yaitu sebesar $50 \%$, responden tidak dapat menemukan informasi mengenai klinik laktasi di RSML dari internet dan juga dari brosur, ini menunjukkan bahwa akses publik terhadap informasi mengenai klinik laktasi di RSML masih kurang. Proses selanjutnya adalah evaluasi alternatif yaitu menunjukkan bahwa sebesar 93,8\% responden menyatakan membandingkan kualitas antara klinik laktasi di RSML, poli KIA dan klinik bidan sebelum menggunakan. Sebesar 68,8\% responden menyatakan bahwa varibel keputusan pembelian terhadap klinik laktasi RSML dalam kategori sedang. Hal ini berarti bahwa responden membutuhkan klinik laktasi, akan tetapi masih belum mantap membeli layanan klinik laktasi RSML, masih adanya pertimbangan untuk memilih pelayanan kesehatan yang lainnya karena layanan klinik laktasi RSML bisa didapatkan di pelayanan kesehatan lain yang sama memberikan konsultasi ASI dan menyusui.

Terdapat beberapa faktor yang dapat mempengaruhi konsumen diantaranya faktor budaya, pribadi, sosial dan psikologis. Salah satu dari faktor tersebut akan memberikan pengaruh yang lebih besar dari pengaruh lain (Setyawati \& Rochmah, 2015:38) dan menurut Pradipta (2016:141), terdapat dua faktor bisa berada antara niat pembelian dan keputusan pembelian. Faktor pertama adalah orang lain, yaitu jika seseorang yang mempunyai arti penting bagi orang tersebut dan berfikir bahwa seharusnya membeli produk sebuah merek tertentu, maka peluang untuk membeli produk merek lain akan berkurang. Faktor kedua adalah faktor situasional yang tidak diharapkan.

\section{Hubungan Brand Awareness, Brand Associations, Perceived Quality dengan Keputusan Pemanfaatan Klinik Laktasi di Rumah Sakit Muhammadiyah Lamongan}

Hasil penelitian menunjukkan bahwa terdapat hubungan antara brand awareness, brand asssociations, perceived quality secara bersama-sama dengan keputusan pemanfaatan klinik laktasi di Rumah Sakit Muhammadiyah Lamongan (RSML). Menurut Durianto (dalam Nujulia, 2013) bahwa brand equity yang kuat dapat terbentuk melalui brand awareness, brand associations, dan perceived quality. Semakin kuat brand awareness, brand associations, dan perceived quality dalam suatu produk 
maka akan semakin kuat pula daya tariknya bagi konsumen untuk membeli produk tersebut dan pada akhirnya akan memberikan keuntungan yang terus meningkat kepada perusahaan. Hasil penelitian ini didukung oleh penelitian Dani, dkk. (2016) yang juga menyatakan brand awareness, brand associations, perceived quality secara bersama-sama berpengaruh terhadap keputusan pemanfaatan pelayanan kesehatan. Hasil uji $\mathrm{R}^{2}$ pada penelitian ini diperoleh nilai $\mathrm{R}^{2}$ sebesar 0,569. Hal ini menunjukkan bahwa kontribusi brand awareness, brand associations, perceived quality terhadap keputusan pemanfaatan klinik laktasi di RSML adalah sebesar 56,9\%, sedangkan sisanya sebesar $43,2 \%$ dipengaruhi oleh faktor lain yang tidak termasuk dalam penelitian ini. Faktor lain yang tidak diteliti adalah seperti dimensi brand equity yang lain yaitu brand loyality dan other proprietary brand asset. Selain itu, menurut Karbalei et al. (2013) masyarakat dalam memutuskan menggunakan rumah sakit dipengaruhi oleh kedekatan geografis (proksimitas).

Variabel brand awareness $\left(\mathrm{X}_{1}\right)$ ketika diujikan secara bersama-sama dengan variabel lain mempunyai hubungan tidak signifikan terhadap keputusan pemanfaatan klinik laktasi di Rumah Sakit Muhammadiyah Lamongan (Y) karena nilai $\operatorname{sig}>(\alpha=0,05)$ yaitu $0,08>0,05$. Hal ini dapat terjadi karena sebagian besar responden yang pernah memanfaatkan klinik laktasi di RSML merupakan pasien yang datang ke klinik anak, tidak klinik laktasi. Selain itu, alasan ke klinik laktasi karena rekomendasi oleh dokter bukan keinginan pasien sendiri. Hasil penelitian ini relevan dengan penelitian Nugroho (2013:154) bahwa brand awareness tidak berpengaruh terhadap keputusan pemanfaatan pelayanan kesehatan. Walaupun brand awareness termasuk top of mind, akan tetapi hasil penelitian menyebutkan tingkat pemanfaatan terhadap klinik laktasi di RSML termasuk sedang. Hal ini dapat terjadi karena pasien mengunjungi klinik laktasi di RSML bukanlah tujuan utama, pasien hanya direkomendasikan oleh dokter poli anak RSML. Kurangnya promosi yang dilakukan oleh rumah sakit terhadap klinik laktasi di RSML merupakan penyebabnya. Menurut Clark, et al. (2009:31) iklan memberikan pengaruh yang positif terhadap brand awareness secara signifikan dan konsisten. Oleh karena itu, RSML perlu meningkatkan promosi klinik laktasi.

Perilaku konsumen dipengaruhi oleh beberapa faktor, salah satunya adalah persepsi. Persepsi konsumen terhadap suatu produk bermacammacam, salah satunya mengenai merek. Merek menjadi salah satu pertimbangan konsumen dalam tindakan keputusan pembelian. Langkah pertama dalam proses pembelian adalah menyeleksi kelompok merek yang dikenal dan dipertimbangkan merek mana yang akan diputuskan untuk dibeli. Merek dapat dikenal dengan melakukan promosi. Merek yang termasuk top of mind memiliki nilai tinggi untuk dipertimbangkan dan dibeli (Nugroho, 2013). Seperti hasil penelitian Setyawati \& Rochmah (2015) menyatakan bahwa brand awareness merupakan kemampuan konsumen mengingat atau mengenali sebuah merek. Masyarakat yang memiliki kesadaran tinggi terhadap suatu merek memiliki pertimbangan tinggi dibenak konsumen dalam keputusan pembelian.

Brand Awareness merupakan first step untuk strategi marketing yang sukses (Alhaddad, 2015) dan merupakan key of asset yaitu jika brand awareness tinggi maka brand equity tinggi sehingga mempengaruhi keputusan pembelian (Nurulaini, 2010). Jadi, jika menginginkan memiliki merek yang kuat sehingga keputusan pembelian tinggi, hal pertama yang harus dilakukan membuat pelanggan selalu menjadikan klinik laktasi RSML sebagai top of mind berdasarkan persepsi responden sendiri.

Variabel brand associations $\left(\mathrm{X}_{2}\right)$ mempunyai hubungan terhadap keputusan pemanfaatan klinik laktasi di Rumah Sakit Muhammadiyah Lamongan (Y) saat diuji bersama-sama dengan variabel lain. Hal ini berarti brand 
associations akan menjadi alasan bagi konsumen pelayanan kesehatan untuk memanfaatkan klinik laktasi. Jika brand associations dengan kategori tinggi dimata pelanggan akan membantu pasien dalam membentuk ciri pada suatu merek yang akan memudahkan dalam membedakannya dengan merek lain sehingga memudahkan pelanggan dalam membuat keputusan untuk menggunakan jasa layanan kesehatan yang akan mereka pilih saat dibutuhkan (Aripka, 2016). Hasil penelitian ini juga didukung oleh penelitian Aripka (2016) bahwa brand association memiliki pengaruh terhadap keputusan pemanfaatan pelayanan kesehatan.

Variabel perceived quality $\left(\mathrm{X}_{2}\right)$ mempunyai hubungan terhadap keputusan pemanfaatan klinik laktasi di Rumah Sakit Muhammadiyah Lamongan (Y) ketika diujikan secara bersama-sama dengan variabel lain, namun memiliki arah hubungna yang negatif, hal ini berarti bahwa perceived quality mempunyai hubungan yang berlawanan arah dengan keputusan pemanfaatan klinik laktasi di Rumah Sakit Muhammadiyah Lamongan. Hal ini dapat disebabkan karena kondisi pasar pelayanan kesehatan yang oligopoli, yaitu produknya hampir sama, responden tidak menemukan keunggulan yang ditawarkan oleh klinik laktasi RSML dari kualitas produknya, dan lainnya. Sehingga responden tidak dapat membedakan antara klinik laktasi dan klinik lainnya yang sejenis. perceived quality merupakan persepsi dari pelanggan maka persepsi kualitas tidak dapat ditentukan secara objektif. Penilaian yang baik mengenai kualitas produk yang sesuai dengan tingkat keinginan konsumen akan mendorong konsumen untuk berminat melakukan pembelian produk tersebut (Pradipta, 2016), kualitas klinik laktasi RSML sudah baik tetapi konsumen mengharapkan kualitas yang berbeda dari pelayanan kesehatan lainnya, bukan kualitas yang hanya sesuai standar tetapi yang mempunyai daya pembeda dengan pesaingnya. Jika tetap sama dengan klinik lain, maka kemungkinan konsumen yang pernah berkunjung ke klinik laktasi RSML tidak akan datang untuk kedua kalinya karena dianggap tidak menarik. Maka RSML harus memberikan kualitas sesuai dengan keinginan konsumen sehingga dapat mendorong mereka untuk memanfaatkan klinik laktasi RSML. Penelitian ini relevan dengan hasil penelitian yang dilakukan oleh Budiasih (2014) bahwa perceived quality berpengaruh negatif terhadap keputusan pembelian.

Branding mempunyai peran yang penting bagi instansi yang bergerak dalam industri pelayanan/jasa, karena merek yang kuat dapat meningkatkan kepercayaan pada produk intangible yang ditawarkan tersebut. Selain menggencarkan periklanan, faktor sukses dalam membentuk Brand Equity yang positif adalah melalui Customer Relationship Management (CRM) (Kim, dkk., 2008).

\section{KESIMPULAN}

Berdasarkan hasil penelitian dan pembahasan, maka dapat disimpulkan sebagai berikut:

1. Terdapat hubungan yang signifikan antara Brand awareness dengan keputusan pemanfaatan klinik laktasi di Rumah Sakit Muhammadiyah.

2. Terdapat hubungan yang signifikan antara Brand associations dengan keputusan pemanfaatan klinik laktasi di Rumah Sakit Muhammadiyah

3. Terdapat hubungan yang signifikan antara Perceived quality dengan keputusan pemanfaatan klinik laktasi di Rumah Sakit Muhammadiyah

4. Terdapat hubungan antara Brand awareness, Brand asssociations, Perceived quality secara bersamasama dengan keputusan pemanfaatan klinik laktasi di Rumah Sakit Muhammadiyah.

\section{SARAN}

Berdasarkan hasil penelitian, pembahasan, dan kesimpulan yang diperoleh, maka saran yang dapat diberikan adalah sebagai berikut. 
1. Bagi peneliti selanjutnya diharapkan mengambil populasi yang lebih luas misalnya ditingkat kota/kabupaten dan juga mengambil masyarakat secara umum sehingga gambaran variabel brandawareness dari pelayanan kesehatan dapat diketahui secara pasti.

2. Menggunakan pertanyaan terbuka dalam pengambilan data Brand Associations agar responden dapat mengasosiasikan sendiri sebuah pelayanan kesehatan sesuai persepsi responden.

3. Peneliti selanjutnya dapat mengembangkan penelitian ini dengan meneliti faktor lain dari Brand Equity yang tidak diteliti oleh peneliti yaitu Brand Loyality dan Other Proprietary Brand Assetyang dapat mempengaruhi keputusan pembelian.

4. Peneliti selanjutnya juga dapat menambah metode penelitian dengan wawancara mendalam sehingga dapat diketahui alasan responden menjawab pertanyaan tersebut secara lengkap pada setiap variabel.

\section{DAFTAR RUJUKAN}

Ahmad, A. M. K., Al-Borie, H., Kamal, E. A., Abdulfattah, F. A., Rhbeini, A. Y.A. 2016. The Impact Of Brand Equity On Patient Purchasing Behaviors In Private Dental Practice In Jeddah, Saudi Arabia.Journal of Business Administration

Research,5(2), 41-55. DOI:10.5430/jbar.v5n2p4.

Alhaddad, A. A. 2015. The Effect of Advertising Awareness on Brand Equity in Social Media.International Journal of eEducation, e-Business, $e$ Management and $e$ Learning,5(2), 73-84. DOI: 10.17706/ijeeee.2015.5.2.73-84

Aripka, N. E. 2016.Pengaruh BrandEquity terhadap PemanfaatanPelayanan
Kesehatan oleh Pasien Umum Pada Instalasi Rawat Jalan di Rumah Sakit IbnuSina YW-UMI Kota Makassar Tahun 2015.Dari http://jurnal.umi.ac.id.

Clark, C. R.,Ulrich, D.,Michaela, D. 2009. The Effect of Advertising on Brand Awareness and Perceived Quality: An Empirical Investigation Using Panel Data. Quan Mark Econ, 7, 207-236. DOI: $10.1007 / \mathrm{s} 11129-009-9066-$ z. Dari http://gsb.stanford.edu.

Dani, F. I., Abadi, M.Y., Palutturi, S. 2016. Pengaruh Ekuitas Merek terhadap Keputusan Pemanfaatan Pelayanan oleh Pasien Umum di Instalasi Rawat Jalan Private Care Center RSUP Dr. Wahidin Sudirohusodo. Dari http://repository.unhas.ac.id.

Fatimah, S. 2014. Pengaruh Kesadaran Merek, Persepsi Kualitas, Asosiasi Merek, Dan Loyalitas Merek Terhadap Keputusan Pembelian Pelembab Wardah Pada Konsumen Al Yasini Mart Wonorejo. Jurnal Sketsa Bisnis, 1(2), 45-57. Dari http://jurnal.yudharta.ac.id

Hussein, M. 2012. Analisis Brand Equity Rumah Sakit Puri Cinere Depok Menurut Persepsi Pelanggan Poli Rawat Jalan Pada Tahun 2012.Tesis tidak diterbitkan. Jakarta: Universitas Indonesia.

Karbalei, M,. Abdi, A., Malmir, R. 2013. Investigating Of Brand Equity On Hospital Image. Research Journal of Applied Sciences, Engineering and Technology, 6(20):3888-3894, 2013.

Kementerian Kesehatan Republik Indonesia.2014. Profil Kesehatan Kabupaten Lamongan, (online).(http://depkes.go.id), diakses pada 31 Januari 2017.

Kementrian Kesehatan Republik Indonesia, Sistem Informasi 
Rumah Sakit Kementerian Kesehatan. 2016.Rekapitulasi Pelayanan Unggulan di Rumah Sakit, (online). (http://sirs.yankes.kemkes.go.id), diakses 27 Januari 2017.

Kementrian Kesehatan Republik Indonesia.2011. Laporan Akhir Riset Fasilitas Kesehatan 2011, (online).(http://.onesearch.kink.k emkes.go.id), diakes pada 18 Oktober 2016.

Keputusan Menteri Kesehatan Republik Indonesia Nomor 603 Tahun 2008 Tentang Pemberlakuan Pedoman Program Rumah Sakit Sayang Ibu dan Bayi.Biro Hukum dan Organisasi, (online).(http://.hukor.kemkes.go. id), diakses 17 Oktober 2016.

Kim, K. H., Kim, K.S., Kim D. Y.Kim, J. H., Kang, S. H. 2008. Brand Equity In Hospital Marketing.Journal of Business Research. 61(2008), 75-82. DOI:10.1016/j.jbusres.2006.05.0 10.

Nugroho, I. S. 2013.Analisis Pengaruh Brand Equity Terhadap Keputusan Masyarakat Dalam Memilih Rumah Sakit Muhammadiyah Surabaya.Jurnal Administrasi Kesehatan Indonesia, 1(2), 147-155. Dari http://www.repository.unair.ac.id

Nujulia, 2013.Pengaruh Brand Equity terhadap Keputusan Pembelian Konsumen pada Produk Pasta Gigi Pepsodent (Studi Kasus Pada Mahasiswa Program Studi Pendidikan Ekonomi STKIP PGRI Sumatra Barat.Pendidikan Ekonomi, 2(2). Dari http://portalgaruda.org.

Nurulaini, N. 2010.Analisa Brand Equity Rumah Sakit Islam Jakarta Menurut Persepsi Pelanggan Rawat Jalan Di Empat Layanan Dasar Padatahun 2010.Tesis tidak diterbitkan. Jakarta:

Universitas Indonesia.

Pradipta, D. 2016. Pengaruh Brand Equity Terhadap Keptusan Pembelian (Survei Pada Konsumen Pembeli dan Pengguna Kartu Perdana SimPATI Telkomsel di Lingkungan Mahasiswa Jurusan Administrasi Bisnis Angkatan 2012 \& 2013 Fakultas Ilmu Administrasi Universitas Brawijaya), Jurnal Administrasi Bisnis,34(1), 138-147.Dari http://administrasibisnis.studentj ournal.ub.ac.id

Rimiyati, H. \& Astutu, D. 2012. Analisis Elemen-Elemen Brand Equity

Rumah Sakit Pku

Muhammadiyah Gombong. Jurnal Medicoeticolegal dan Manajemen Rumah Sakit, 1(1). Dari http://journal.umy.ac.id.

Setyawati, C.\& Rochmah, T. N. 2015.Pengaruh Brand Knowledge Terhadap Pemilihan Rumah Sakit.Jurnal Administrasi Kesehatan Indonesia, 3(1), 3139.Dari http://ejournal.unair.ac.id.

Shahid Z., Hussain, T., \& Zafar, F. 2017.The Impact of Brand Awareness on Consumer Purchase Intention: Journal of Marketing and Consumer Research, (Online), 33. 34-38. (http://www.iiste.org), diakses 4 Juli 2017.

Vinodhini, Y. \& Kumar, B.M. 2010. Brand Equity In Hospital Marketing. Summer Internship Society, 2(2010), 89-93. Dari http://sdmimdjournal.in.

Zen, D. K. M. 2012. Analisis Pengaruh Ekuitas Merek Terhadap Keputusan Pembelian Konsumen Minuman Isotonik Pocari Sweat (Studi Pada Mahasiswa Fakultas Ekonomika Dan Bisnis 
17 | Jurnal Preventia Vol. 3 No. 2 Desember 2018

Universitas Diponegoro

Semarang). (Online).Skripsi tidak diterbitkan. Semarang: Universitas Diponegoro. 